\title{
Värvisõnad ja värvisümbolid eesti mõistatuste alaliikides
}

\begin{abstract}
Piret Voolaid
Teesid: Artiklis analüüsitakse võrdlevalt värvinimetusi eesti mõistatuste levinumates alaliikides (klassikalised ehk tavamõistatused, keerd- ehk naljaküsimused, piltmõistatused ehk reebused), keskendudes iga alaliigi spetsiifilistele omadustele, liigist tulenevatele erinevustele. Põhiküsimus on, millised on alaliigiti sagedasemad värvinimetused ja millistes üldisemates kasutusseostes need esinevad. Klassikalistes mõistatustes kui arhailisimas mõistatuste kihistuses on kujund enamasti suunatud lahendobjekti välimusele, meeleliselt tajutavaile külgedele. Värvinimed on klassikaliste mõistatuste kujundiloomes rohkelt esindatud, olles mõistatuse objekti, eseme või nähtuse kirjeldamisel ja lahendivihje andmisel üks esmaseid tunnuseid. Keerd- ehk naljaküsimused ja piltmõistatused on keskendunud huumorile ja neis väljendatakse värvuste kaudu kultuuristereotüüpe.

Tekstinäited pärinevad internetiandmebaasidest "Eesti mõistatused" (Krikmann \& Krikmann 2012), "Eesti keerdküsimused" (Voolaid 2004) ja "Eesti piltmõistatused" (Voolaid 2002), mis põhinevad peamiselt Eesti Rahvaluule Arhiivi käsikirjalisel ainesel, kuid ka erinevates trükistes ja internetis leiduval materjalil.
\end{abstract}

Märksõnad: folkloristika, keerdküsimused, klassikalised mõistatused, liitsõnamängud, mõistatused, piltmõistatused, värvinimetused, värvused

\section{Sissejuhatuseks}

Värvinimetused ja värvused eesti folklooris on olnud mitme žanrikeskse uurimuse huvisfääris, nt regilaulus värvinimetused pulmalaulude kujundina (Roll 1985), värvivormelite kasutus regilaulus (Jaago 1997; Jaago 2016), punane värvi ja sõnana regilaulus (Sarapik 1997) või värvide tähendusväljad muinasjutus (Toomeos-Orglaan 2016; Sutrop 2016), värvuste sümboolika loitsudes (Kõiva 2016). Uurijad on rõhutanud ka värvuste osatähtsust mõistatustes, nt absurdimaigulistes keerdküsimustes (Lipponen 1995; Dundes \& Abrahams 1987). Eesti mõistatustes on temaatikat riivamisi käsitletud veel nt Mikk Sarve ja Tõnn Sarve (1979) artiklis "Loomise lugu", milles toodi mõistatused esile tõlgendusseostes eestlaste maailmapildiga. ${ }^{1}$ Arvo Krikmanni veebiõppematerjalist 
"Eesti mõistatuste kujundid" (Krikmann 2000jj) ilmneb aga kaude värvuste osatähtsus mõistatuste semantilis-leksikaalses kujundiplaanis (kujundistereotüüpides ja vormimallides). Astrid Tuisk (1996) on ettekandes "Elevant kaasaja folklooris" rõhutanud värvide sümboltähtsust elevandiga seotud pärimuses, sh keerdküsimustena kvalifitseeruvates elevandiküsimustes.

Žanrist lähtuv uurimine võimaldab tulemusi omavahel võrrelda. Käesolevas artiklis keskendun värvinimetuste kasutusele mõistatuste levinumates alaliikides, ent vaatlen mõistatuste alaliike võrdlevalt, sest värvinimede kujundilisus on alaliigiti spetsiifiline. Vanim ja arhiivitekstide põhjal seniajani rohkearvulisim alaliik (umbes 100000 üleskirjutust) on klassikalised, tavalised ehk pärismõistatused, mis on oma olemuselt mingi objekti, eseme või olukorra poeetilised kirjeldused. Värvinime sisaldav kujund - sõnaühend võib neis olla nt kahesõnaline metafoor hall härg (Hall härg, seljast sööb?), viidates veskikivile. Hilistekkelisematest ja tänapäeval levinumatest alaliikidest on populaarsemad ja arvukamad (umbes 25000 üleskirjutusega) keerdküsimused - küsisõnalise või küsisõnaühendilise algusvormeliga mõistatused, mille puhul on küsija eesmärk enamasti vastaja narritamine ja naljasaamine (Mis värvi on keisri valge hobune? - Valge). Toodud kahe näite varal ilmnevad värvikujundi erijooned kahes nimetatud alaliigis. Erinevalt klassikalise mõistatuse "halli härja" näitest ei ole keerdküsimuses "valge hobune" metafoor, vaid küsimus ise ongi valge hobuse kohta. Kui klassikalise mõistatuse juhul (hall härg) peaks toimima kujundiline fantaasia (mis võiks olla nagu hall härg), siis siin on oluline pigem tähelepanelikkus (küsimuses endas on olemas ka vastus - hobune on valge).

Graafilist folkloori esindavad (umbes 8000 üleskirjutusega) piltmõistatused, mille küsimuspoole moodustab paberile joonistatud (tavaliselt) minimalistlik pilt koos selle juurde esitatud küsimusega Mis on pildil?, vastuseks on aga pildil oleva nähtuse, eseme, tegevuse, olukorra ühe sõna või lausena antud kujundlik kirjeldus

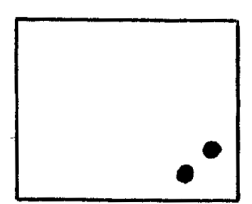

(Mis on pildil? Punapead ujuvad Valges meres). Mustvalge pildi värvikujundis sisaldub tihtipeale nii visuaalse kujutlusvõime esilekutsumine (pildil olevad täpid on ju mustad) kui ka värvi olemasolu küsimus- ja vastuspooles.

Analüüsis on põhiküsimustena tähelepanu all mõistatuste värvisõnavara, värvinimetuste esinemissagedus alaliigiti, samuti see, millistes üldisemates kasutusseostes värvinimetused esinevad ning kuidas rakendatakse värvusi kujundiloomes ja sümbolite konstrueerimises. 


\section{Värvinimetused klassikalistes mõistatustes}

\section{Värvinimetuste esinemissagedus}

Hüpoteetiliselt kasutatakse värvusi ja värvinimesid klassikalistes mõistatustes sagedasti sellepärast, et värvus on millegi kirjeldamisel ja lahendivihje andmisel üks esmaseid ja otseseid välistunnuseid. Eesti Rahvaluule Arhiivi materjali põhjal koostatud tuntumate mõistatuste esisaja (vt Krikmann 1997: 176-181) põhjal võib samuti öelda, et suur osa populaarsemaid tekste sisaldab tunnusena värvust. Kaks sellist näidet leiab seejuures enim levinud mõistatuste esikümnest:

2. Seest siiru-viiruline, pealt kullakarvaline keeruline? - Sibul. (EM 1920)

10. Must siga läheb lauta, ajab punased põrsad välja? - Ahjuroop. (EM 1302)

Sibula-mõistatus ongi 2007. aastal toimunud üle-eestilise koolipärimuse kogumisvõistluse tulemuste põhjal tänapäeva tuntuim klassikaline mõistatus, mille küsimuspooles esineb oluline vihje objekti värvusele (kullakarvaline). Küsitluskavale vastati seda 82 korral (vt Voolaid 2010: 130).

Klassikaliste mõistatuste värvinimetuste statistiline analüüs tugineb andmebaasile "Eesti mõistatused" (www.folklore.ee/moistatused). Baasi aluseks oli 2800 Word 7.0 formaadis tüübitabelit, mille põhjal valmis akadeemilise väljaande Eesti mõistatused (EM) põhiköidete I (2001) ja II (2002) käsikiri. Andmebaasis on 95751 mõistatusteksti, mis jagunevad 2800 sarnastest variantidest koosnevaks tüübiks. Värvileksika statistikas (tabel 1) on arvesse võetud vaid mõistatuste tiiteltekstid ehk tüübipead (samasisulistest variantidest koosneva tüübi esindustekstid), mis kannavad identseid tüübinumbreid. Ainult tiiteltekstide arvestamine on põhjendatud, sest rohkete variantidega produktiivsed tüübid mõjutavad tulemusi: näiteks kui mõni värv on esindatud ühes suures mitmesajavariandilises tüübis, võimendab see petlikult selle värvuse esindatust.

Klassikaliste mõistatuste andmebaasist värvinimede otsingu tulemusel saadud värvinimede esinemise sagedussõnastik (vt tabel 1) osutab, et 11-st eesti keele põhivärvinimest (valge, must, punane, kollane, roheline, sinine, pruun, hall, lilla, oranž ja roosa, vt Sutrop 2011: 80) on klassikalistes mõistatustes esindatud kõik peale lilla ja oranži. Värvinimetustest kõige sagedasemad on must (esineb 190 tiiteltekstis), valge (108 tiiteltekstis) ja punane (89 tiiteltekstis), mis ongi enamikus keeltes ühtlasi vanimad värvisõnad (Viires 1983: 291) ja 


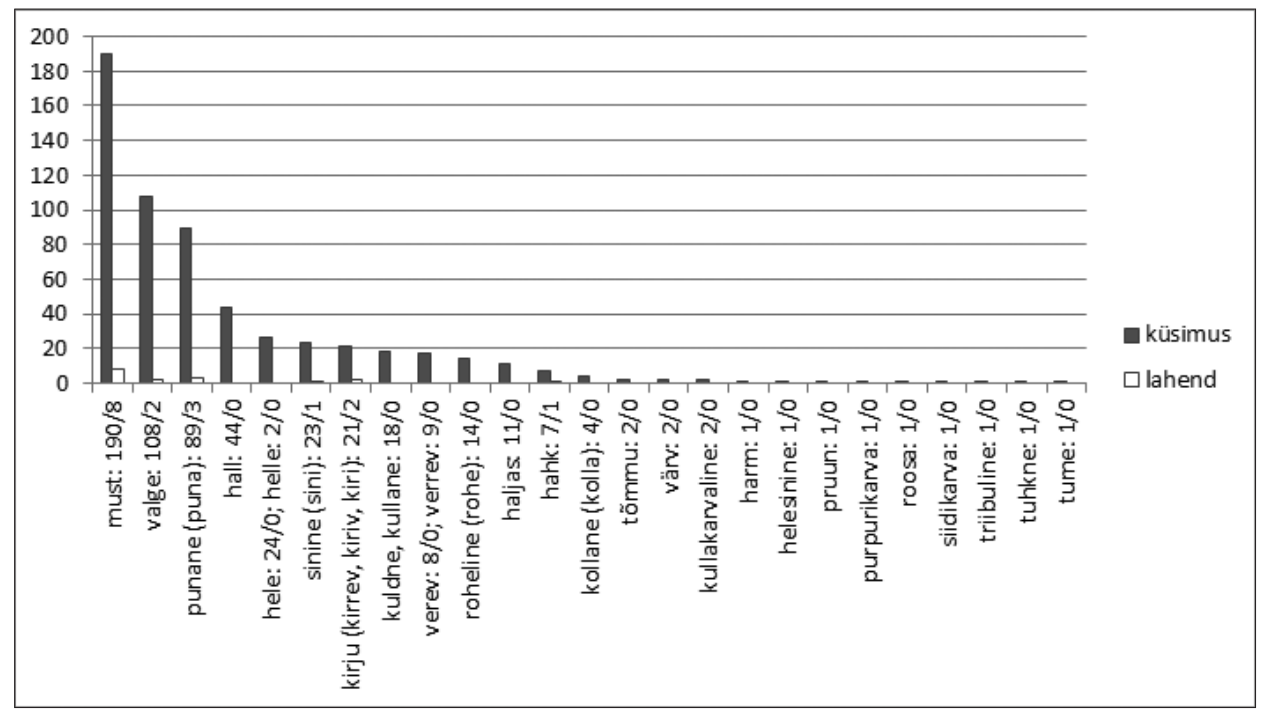

Tabel 1. Värvisõnade esinemissagedus klassikaliste mõistatuste küsimus- ja vastuspooles andmebaasi "Eesti mõistatused" põhjal. Otsingus arvestatud 2800 tiiteltekstist esinevad üks või enam värvinime küsimuses 587 ja lahendis 17 korral.

põhivärvinimed (Sutrop 2011: 80). Tõsi, valge ei pruugi tähendada alati valget värvust, vaid ka valgust, nt Kui pime, sis valge, kui valge, sis pime? - Tuli, vt ka Viires 1983: 293).

Punase kõrval eksisteerivad 17 mõistatustüübis iidsest soomeugri sõnast veri tuletatud lõunamurdelised verev ja verrev. Ühel korral esineb punast laiendav liitvärvinimeline täpsustus purpuripunane pääsukese mõistatuses (Ork ees, hark taga, pealt sinine siidikarva, alt punane purpurikarva, sibinal ja sabinal saksa keelt reegivad?). Samas mõistatuses kohtame väljendit siidikarva tähenduses sinine, kuid sellist kombinatsiooni võib toetada si-alguskaashääliku kordus.

Populaarsuselt neljandal kohal on hall (esineb 44 tiiteltekstis, samas on halli kõrval seitsmes tüübipeas esindatud ka lõunaeestiline hahk), millele järgneb hele/helle (26 tiiteltekstis) ehk valgusega seotud värvitoon. Huvitaval kombel leidub tume kui heleda vastand seejuures ainult ühes akna mõistatustüübis EM 210 (Hele täht, tume täht, rikka mihe maja külles?). Pingerea kuuendal kohal on sinine (23 tiitelteksti). Teisi värve leidub juba vähem. 20 mõistatustüübis on ära toodud kirju eri murdevormid (kiri, kiriv, kirrev), 18 tiiteltekstis leiduvad aga kuldne ja kullane, samas kui sellele lähedane kollane figureerib ainult nelja mõistatustüübi tiiteltekstis. 
Klassikalised mõistatused on muude alaliikidega võrreldes vanim ainekiht, mistõttu ongi neis peidus arvestatav hulk arhaisme. Nii kasutatakse siin värvinimega roheline (esineb 14 tiiteltekstis) pea võrdselt (11 tiiteltekstis) arhailist vormi haljas. Kogu mõistatuste korpust arvestades leiame värvinime haljas lausa 406 kirjapanekus 27 tüübis, samal ajal kui roheline on leitav kõigest 111 kirjapanekus 22 tüübis (vt joonis 1 ja 2). 17. sajandi sõnastikes esineb haljas üksmeelselt saksa sõna grün tähenduses, kuid tänapäeva eesti keeles tähendab see põhiliselt haljendavat ja vahetult värvi tähenduses seda ei kasutatagi (Viires 1983: 296). ${ }^{2}$

Mõistatustes on olemas ka üldnimi värv / värvi ning kõigis läänemeresoome keeltes tuntud värvust märkiv sõna karv/karva (kullakarvaline, purpurikarva ja siidikarva).

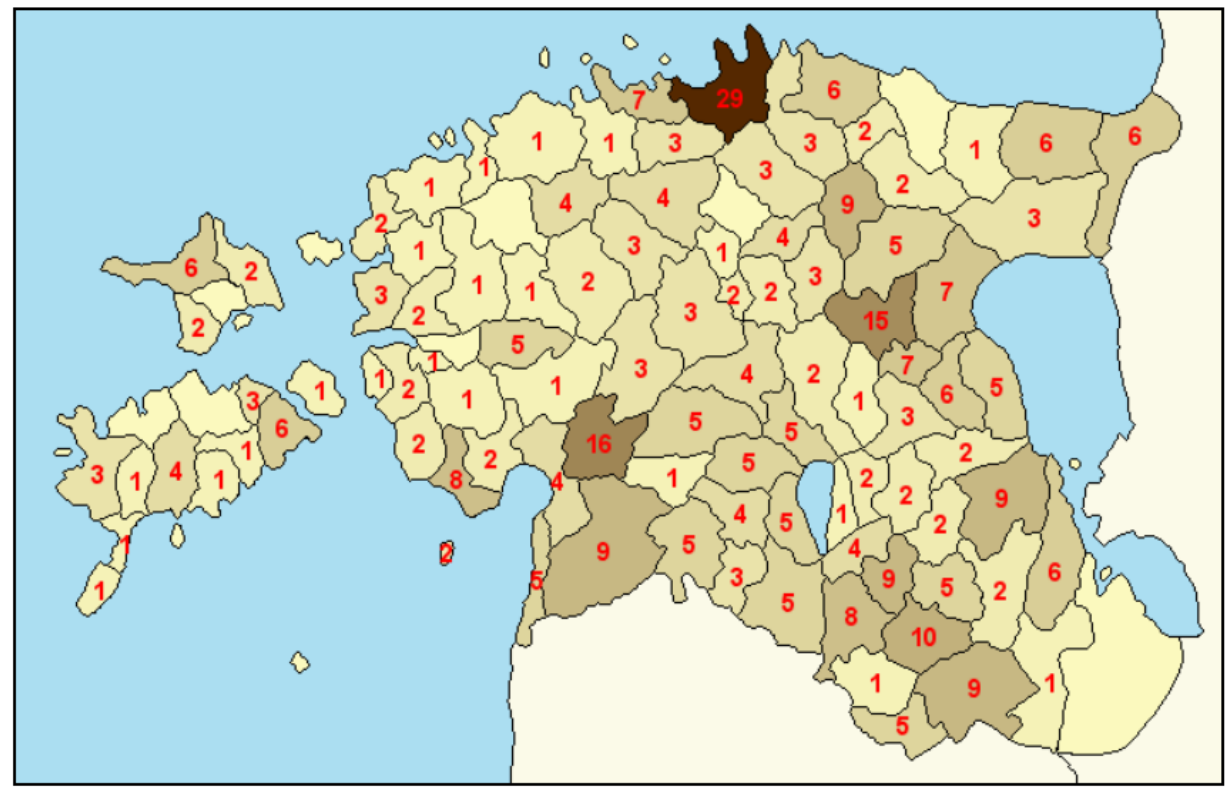

Järjend haljas mõistatuse tekstis

Kokku 406 kirjapanekut 27 tüübist

Kaardilt puuduvad: As 1, Lut 1, Sa 2, Trt 9, Tt 6

Joonis 1. 


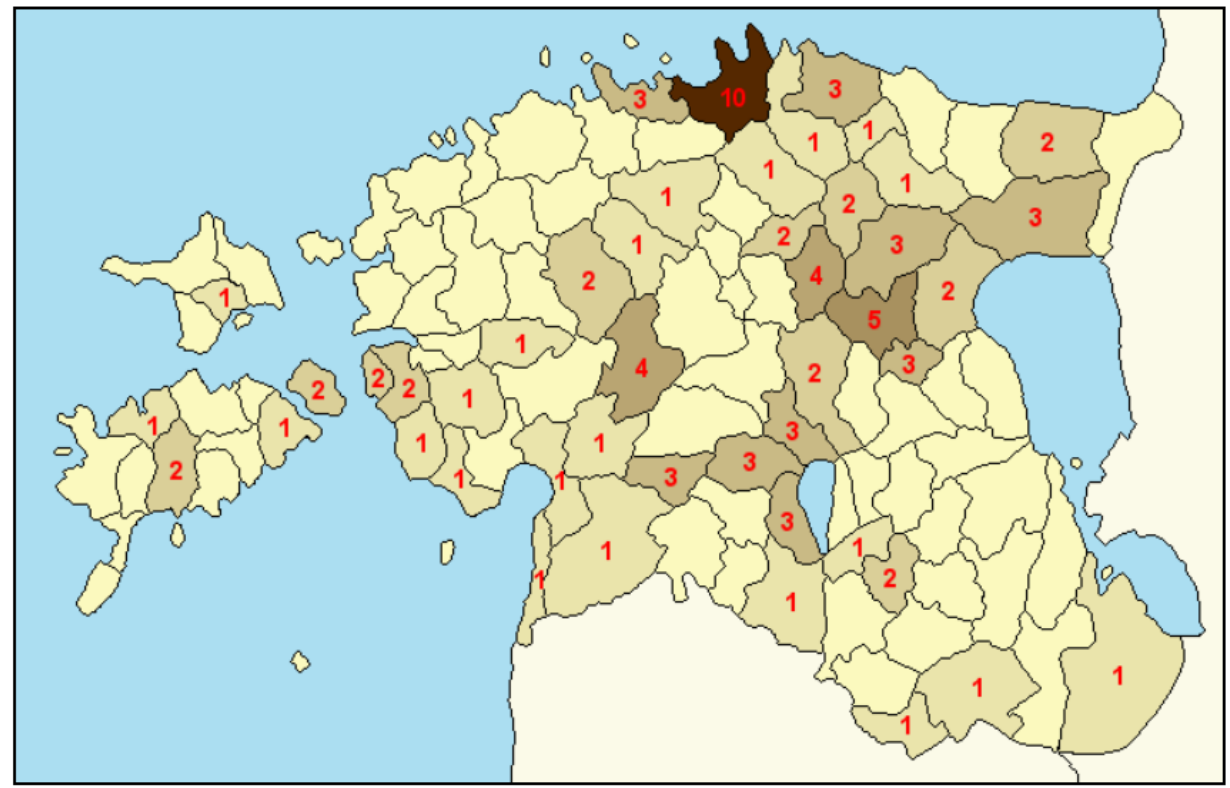

Järjend roheli mõistatuse tekstis

Kokku 111 kirjapanekut 22 tüübist

Kaardilt puuduvad: As 2, Elv 1, Sa 3, Ta 1, Tln 1, Trt 6, Tt 3

Joonis 2 .

\section{Värvinimetused kujundiloomes}

Peale andmebaasist värvinimede otsingu tulemusel saadud sagedussõnastiku pakub huvi, millistes kujundiseostes värvinimetused mõistatustes esinevad. Klassikaliste mõistatuste kujundiplaane on varem põhjalikult analüüsinud Arvo Krikmann (2000jj) oma õppematerjalides, milles on ta mõistatused jaganud kujundiloometehnika poolest laias laastus kaheks:

1) määratletud subjektiga või "agendiga" mõistatusteks, kus "kujundil on mõisteregiooni selgelt fikseeriv substantiivne või agenti osutav "tipp", s.t kirjeldaval lausel on süntaktiline alus" ja

2) määratlemata subjektiga või "agendita" mõistatusteks, kus "selline substantiiv-agentiivne "tipp" puudub ja mõistatatav objekt esitatakse tegevuste, omaduste, suhete, kohtade, aegade vms kaudu kaude ja "anonüümselt" (kuigi neis predikaatides võib olla vahel ilmseidki vihjeid referendile endale)". 
Mõlemal juhul osalevad kujundiloomes ka värvinimetused. Esimesel juhul on määratletud subjektil tihtipeale värvile viitav omadus. Sageli on subjektiks "zootermin", mille juures mängib olulist rolli värvus. Krikmanni (ibid.) järgi on looma- ja linnunimedel põhinevate metafooride edetabel: 1) veised - 85 teksti; 2 ) sead - 51;3) hobused - 49; 4) lambad-oinad - 43; 5) kana-kukk - 42; 6) koerad - 40;7) lind, tsirk (üldnimena) - 24;8) kitsed-sokud - 20;9) karu - 20; 10) hunt, susi - 19; 11) hiir - 15; 12) hani - 13.

Värvinimi kui täiend on vältimatult ja lahutamatult seotud nende alussõnadega, sagedasim värvi ja looma koosluses tekkiv metafoor on seotud härg-subjektiga, sh üheksas mõistatustüübis esinev hall härg, mis võib tähendada jahve- ehk veskikivi ${ }^{3}$ (Hall härg möirab nurkas? Hall härg, auk seljas?), tuuleveskit (Hall härg, hangus sarved, võtab sauna sarvile, kihelkonna kukile?), talutuba (Hall härg, kahes otsas hangus sarved?), võid pudru sees (Hall härg, mäda selg?), ussikoda (Hall härg, sarved peas, tõld tuudeldi taga?), õllevaati (Hall härg, allikas sel'las?), heinakoormat (Hall härg, valge sarve?). Enamasti sisaldab halli härja stereotüüp ha-alliteratsiooni, sobiv hääliku-heakõla võibki olla halli härja rohkuse primaarseid põhjusi. Kuigi metafoori tähendust kannab pigem loom kui värv (härg tähendab tavaliselt midagi suurt ja liikumatut, lehm pigem mingit karja või hulka, vasikas midagi liikuvat-häälekat), ent siiski on võimalik värvinimetusi esile tuua. Nii kohtab halli lehma stereotüüpi nt taarikeha tähenduses (Hall lehm ühe nisaga, toidab kõik oma pere piimaga?). H-alliteratiivne hall hobu(ne) võib olla kirik (Hall hobu, harmi jala, istub püha põllu peendra pääl?), jõgi (Hall hobune, rohelised aisad?), kuu (Hall hobune vahib üle katuse?). Lõunaeestiline värvisõna hahk tuleb esile nii lamba kui ka oinaga seotud mõistatuskujundeis.

Hahk lammas tähendab kinnast (Hahk lammas, hand küllen?), hahk oinas võib olla nii pilliroog (Hahk oinas orre otsan?) kui ka nööridega hahk särk (Hahk oinas, hangu sarvõ', verevä' villa', pükä ei saa?). Esinevad ka hall kits vokina (Hall kits, kekud sarved, läheb läbi taarutse tänava, hall habe suus?) ning hahk sikk heinakuhjana (Hahk sikk, ahara sarve, vedävä üles taiva poolõ?). Metsloomadest esineb hall hunt kui ilus alliteratiivne stereotüüp üllatuslikult ainult ühes tiiteltekstis oherdina (Hall hunt, saba suus?). Ilmselt põlenguga kaasneva suitsu ja vingu värvuse tõttu on halli kuke tähendus maja põleb (Hall kukk, punane hari?). Hall kass on tuntud adrana (Alt jookseb hall kass, päält kü̈̈rakas rebane?)

Must härg, millega kaasneb m-alliteratsioon, esineb seitsmes tiiteltekstis ja võib olla lõõts (Must härg magab, sarv läbi seina?), õpetaja kantslis (Must härg müirab tampse tôrre sees?), lambarauad (Must härg, mugalised sarved, [kolm] korda sööb aastas?), aidavõti (Must härg, mugulad sarved, läheb järvejäe pääle, pistab sarved sisse lopsti?), viinakatel (Must härg, munatsõ sarvõ, 
võtt kulla kukruhe, vasõ varbihe?), kirp (Must härg, mügarad sarved, käänab lihase paku ümber?), sepp ja lõõts (Tikk-takk lööä, must härg vedäjä?). Samuti eksisteerib must lehm väga erinevates lahendites: talirukkid (Mullu poigis must lehm, tänävu sü̈̈̈ ternepiim?), torupill (Must lehm, mugurad sarved, kena lehm, keigud sarved, tuli ammudes arusta, ihkudes Ihasalusta, ei ole kõhus kõrrekesta, maus ei marjavarrekesta, ise täis kui tiine puuki?), teekann (Must lehm, üts kõrv, üts nisa?), saunakeris (Musta lehmä mulle-rulle, tuorvitäüe vettä joone?). Tõmmu lehm on linakupar (Tõmmu lehm tõtsa-vatsa, igas vatsas vasikas? Tõmmu lehmal viis udart, igas udaras üks poeg?). Must esineb sageli ka parallelistlikes järjendites, nt must : punane : roheline, kus must hobune on saunas vihtlemine (saunas vihutakse) (Must hobu, punane mees, rohiline piits?), must : kuldne, kus must kits puupäsmer (Must kits, kuldse nisa?). Nii nagu hall härg tähendab kinnast, võib sama tähendada ka must lammas (Must lammas, valge moka?). Mõistatuse lahendajat abistava kujundilise loomsubjektina on levinud ka siga ja põrsad, sageli on must siga saunakeris (Must tsiga, mulke täis?), käibel on must siga/emis, punased põrsad parallelistlik kooslus, nt ahjuroop (Must siga läheb lauta, ajab punased põrsad välja?), kolle (Must emis nurkas, punased põrsad põlle sees?). Ka koduloomad koer ja kass on ühendkujundina esindatud. Nii must koer kui ka must kass on mõistatustes pada (Must koer koldes, liha ta sööb ja rasva ta neelab, aga siiski suuremaks ei kasva? Must kass, aidavares?), must koer lisaks ka kirikuõpetaja (Must koer, valge kurgualune?).

Iseäranis paljudes mõistatustes eksisteerib produktiivne algusstereotüüp must kukk, mis võib esineda väga erinevates tähendustes, nt vasklukuga piip (Must kukk ja kuldsed mokad?), mõtus (Must kukk ja mugurad silmad, ise nöpib nööpnõelu?), õpetaja kantslis (Must kukk kutsub kõik kihelkonna kokku? Must kukk kuuse otsan, viskab paska viljäle? Must kukk, valged lõpuksed?), kardraiustega särk (Must kukk, kuldsed kannuksed), kannel (Must kukk, kuldsed sarved? Must kukk, kuldsed sooned?), püss (Must kukk, kuldsed siived?), pada tulel (Must kukk, kuldsed suled?), pudel (Must kukk, muru hari?). Must kana võib olla kaal (Must kana, hahk muna?) ning pada süte peal (Must kana, verevä muna?), must hani on vastusena must särk, mitte hame (Must hani ilma pääte?). Lisaks leidub lind üldnimena, nt must lind võib tähendada pada tulel (Must lind, punased munad?), aga kirikuõpetajat (Musta lindu, madala jalga, valge kurkalune, sealiha tema sööb, kanamuna tema joob, kuus päeva tema magama, seitsmendal laulma: puh-puh! Mis lindu see on?).

Ka valge on loomkujundi täiendina populaarne. Kolmel korral esineb mõistatuste algusvormelina valge härg, mis võib olla nt kaljakapp (Valge härg magab mäe pääl, igaüks annab musu?), kirik (Valge härg mäe otsas, üks sarv pääs?), jala varvad (Valge härg, viis pääd?), valge lehm on mahlakask ehk -kõiv 
(Valge lehm, must piim? Valge lehm, sada sarve pä̈̈s, ühest nisast küpsetas?), valge hobune kui kirik (Valge hobune vainul, kõht konne täis?). Mitmuses esinevad valged lambad on aga herned pajas (Valged lambad hüppavad meres?), valged kanad omakorda võivad hulgi esinedes stereotüüpselt tähendada hambaid suus (Kaks õrretäit valgeid kanu? Punane õrs valgeid kanu täis?). Haruharva ehk ühel korral esineb valge peaga must vasikas kui vahutav oja (Must vasikas, valge pea?) või vaht ([Teeliba, maasuga, metsakukk, meresikk,] ranna valgepää vasikas?).

Suust valget vahtu ajav kult võib olla käsikivi (Pahrukene nulgah, aa valget vattu suust vällä?) või veskikivi (Vana oorik valge vahu sees?). Murdeline valge tsirk assotsieerub lumega (Kats valget tsirkukõst taplõse katuse pääl?).

Loomametafooride analüüsimisel sobib kaasata zooabsurdi ideed, mida Arvo Krikmann on juurutanud vanasõnade uurimisel, osutades konstruktsioonidele, kus loomale omistatakse tunnuseid, mis tal tegelikkuses puuduvad, kuid on olemas mõnedel teistel loomadel (peaasjalikult kehaosi, kuid ka värve, võimeid elada teatud keskkondades jne.), samuti katseid saada loomalt mõnd "vale" toodet (villa, piima vm) (Krikmann 1999). Värvide ja loomametafooride kooslused on klassikalistes mõistatustes nii mõnigi kord reaalsusega vastuolus ja tulenevad lahendist, vajadusest vastajat õige lahendi leidmisele just lahendobjekti värvuse abil lähemale aidata.

Ka rahvusvaheline zooabsurdne konstruktsioon, eesti keeles va-alliteratiivne valge vares on mõistatustes olemas, ühes Lutsist kirja pandud tekstis, mille lahendus kerkesänd võtt patale (Valge vares lävi aia latsi ravitses?).

Värvinimed punane ja verev on samuti loomkujundi olulised osised. Pu-alliteratiivne punane pull on sageli jõhvikas (Punane pull kasteheina kütkes? Punane pull, seest sappi täis?) ja selle sünonüüm kuremari (Punane pullike, jõhvist lõake?), aga ka tulekahi (Punane pullike juusk saina mü̈̈d̈̈ üles?). Punane hobune on tuli ja suits (Punane hobune, must saba?). Punane koer on keel (Punane koer haugub läbi luise aia?), tuluk leedes (Punane koer magab jahukerstus?) või tuli (Punane koerake raksub raudriides?). Nii nagu punane kukk on keeles väga levinud väljend tulekahju kohta, on ta ka mõistatustes tulekahi (Punane kukk katusel?). Siinkohal tuleb rõhutada, et artikli huviorbiidist jäid välja mõistatuste alaliigina tänapäeval suhteliselt levinud liitsõnamängud, kuivõrd värvinimesid neis ei esine. Siiski on üks liitsõnamõistatus seotud sellesama punase kuke ('tulekahi, tuli') liitväljendiga: Millist kukke ei sallita? - Punast kukke. Verev tuleb ette kooslustes verev lehm kui päike (Verrev lehmäkene sü̈̈ läbi aia läätsi?) ja verev hani kui kõrv (Verrev hani mäe küllehn kükütäs?).

Roheline loomkujundi elemendina puudub, kuivõrd on ebarealistlik. Erandi moodustab siin ha-alliteratiivne stereotüüp hani haljas, mis võib olla pudel 
(Hani haljas, pea paljas, pea päält läheb auk sisse?) ja viht (Hani haljas, pea paljas?), samuti sobib vastuseks: kalla pudelist piima (Hani haljas, perse paljas, viskas paska vurtst?). Kui üldiselt eelneb värvinimi loomaterminile, siis hani haljas tõestab vastupidist järjekindlust. Nii nagu regilauludes võivad värvused esineda väljakujunenud sõnaseostes (Jaago 2016), on hani haljas näide mõistatustes esineva vormel-stereotüübi või kinniskujundi kohta.

Mõistatustes on kasutusel ka täiend kirju, mis ei tähista otseselt värvi, kuid viitab värvilisusele. Enam esineb kirju lehm, nt kanepiterä (Kiriv lehmäkene, valgõ piimäkene?), tuulik (Kiri lehm ning keerd sarved, haniväljal ammub, siniväljal singub?), vokk (Kiri lehm, kikkis sarved?), laev (Kirju lehma, keikud sarved, konnib järve jäe peal, jäe pa[u?]kub ja veri väriseb?). Kiri kass on õllekann (Kiri kass kükitab laual, valget vahtu seest täis?).

Peale loomametafooride leidub mõistatustes rohkelt värvi ja inimese kombinatsioonis esinevaid (nii metonüümilisi kui metafoorseid) kujundeid, mille juures samuti värviepiteedil oluline roll. Must mees on 10 mõistatustüübi algusvormel ja tuleb ette väga erinevates tähendustes: kiriksand ja kogudus (Must mees marsib sauna, sada sammuvad järele?), esimesega lähedane köster ja kirikherra (Vanamees mängib kiikapilli, must mees kärkab tõrre sees?), püss (Must mees mehemurdja?, Must mees sülitab üle metsa?), kikas (Must mees muru pääl, tükk liha turja pääl?), taaritõrdu (Must mees nurgas, viskab kust?), pääsuke (Must mees, kalasaba taga?), nööritatud särk, vammus (Must mees, punatse hamba?), Maa (Must mees, roheline kuub selgas?). Põnev on lahendus "tulejalg, kelle peal peerg põleb", mille puhul kogu nähtus kõigi oma osadega on kirjeldatud värvisõnade abil: Must mees, mustad mokad, punane piip, valge vars?

Punane poisike on algriimi põhjal sarnane punase pulliga, lahenduseks valdavalt marjad: nt lillakas (Pisike punane poisike, kivine kõhuke?), murakas (Punane poisike magab rohelise palaka pääl?) ja kibusemari (Punane puppis poisike, süli saiakakka täis?). Aga leidub muidki vilju: nt porgand (Punane poiss, rohelised juuksed?; Punane poisike musta asema sees?) või õun (Verreva külega poisikene üles puut?). Samas on lahenduseks ka keel ja hambad (Neitsid tantsivad, punane poisike vahel?) või pliiats (Punane poisike, kivine süda?). Sõnaühend valge poisike võib tähendada uba (Valge poisike, must nina peas?).

Tekstide põhjal on ilmne, et värvivalikud lähtuvad paljuski poeetilise kujundi kohustuslikust häälikuharmooniast, algus- ja lõppriimist, parallelistlikest vormelitest. Samas on väga suur osa visuaalsel kujutlusel - hall härg veskikivina ei saa olla must härg või suur härg vms; must härg on samuti võimalik (kuigi ei moodustu algriimi baasil vormeli - metafoori - ulatuses, algriimub mõne teise sõnaga lauses - Must härg müirab) ja on alati ka mingi värviseosega nähtuse (kirp vms) tähenduses. 
Niisiis on kujundi mitmetasandilisuse (metafoorid, metafoorsed epiteedid) ning metafoori (küsimuse) ja selle aluse (lahendi) omavaheliste seoste tõttu (nt hall härg kui kahesõnaline metafoor veskikivi kui ülekande tähenduses) keeruline allutada klassikaliste mõistatuste värviaspekti ühtsetele alustele. Kuigi materjali põhjal lähtuvad otsingud värvisõnast ja käsitlus - kujunditõlgendus - omakorda loomametafoori (zootermini) või inimkujundi mõistest, on õigem vaadata neid nimelt metafooridest lähtuvalt ja käsitleda neid kui tervikkujundit.

Teiseks vaatleme määratlemata subjektiga mõistatusi (umbes veerand klassikalistest mõistatustest). Siin saab omaette alateemana välja tuua värvinimetuste paiknemise mõistatuses kui lauses, värvinimetuste kasutusalad mõistatuse üleehituses või struktuuris, sest tihtipeale kohtab värvinimetusi mõistatuste küsimuspoolele omastes teatud vormimallides. A. Krikmanni (2000jj) järgi asuvad troobi puudumisel tööle teised struktuuritasandid, "väljaspool eeldus-järeldusstruktuure on agendita mõistatustes alatasa näha, kuidas nimepidi nimetamata asja olemuses või käitumises luuakse mingit telge pidi "ruum", tuuakse välja mingi erinevus, vastuolu, piirjuhul paradoks, ühtlasi luuakse seeläbi elementaarne parallelism". Käesoleva artikli kontekstis on huviväärne värvide esinemus neis vormilistes stereotüüpides. Enamasti on küsimuspooles kõrvutatud või vastandatud kaks kohta või ruumiaspekti:

Alt/seest..., pealt...

Alt roheline, pialt sinine? - Lina

Alt sirelt-säreline, pealt kullakarvaline? - Kangasjalad

Seest must, pealt punane? - Löör

Seest siiruviiruline, pealt kullakarvaline? - Sibul

Seest sile ja punane, päält must ja karvane? - Muhv

Pealt..., alt/seest...

Pealt valge, seest punane? - Inimene

Päält valge, seest must? - Lumi ja maa

Pealt must, seest punane, pistad sisse, on mõnus? - Kaloss

Üles..., alla...

Viskad ülesse, on valge, kukub maha, on kollane? - Muna

Eest..., tagant/otsast...

Eest punane, tagast karvane? - Maasikas

Värvinimed võivad küsimuspooles esineda ka kahe ajahetke või -vahemiku kõrvutustel-vastandustel põhinevatel sümmeetrilistel stereotüüpidel. 


\section{Ennelesite ..., pärast ...}

Enne lai ja kollane, pärast valge ja ümmargune? - Võilill

Esite pisike ja punane, pärast ei mahu püksi? - Pähkle õis

Esiti valge kui lumi, pärast kui haljendav rohi, viimati verev kui veri, lapsile magus kui mesi? - Kirsimari

Üldiselt on värvidel põhinev kujundikasutus mõistatustes väga kirev, küsimused võivad põhineda ka üksikvärvil, kuid sagedasti kasutatakse parallelistlike korduste eesmärgil värvipaare ja -kolmikuid. Pole juhus, et levinumad paarid on esinemissageduse statistika pingereas võimsalt esindatud värvinimed, nt vastandpaar must : valge, aga ka valge : punane; must : punane; valge : kollane; must : kollane; punane : roheline; roheline : sinine; hall : roheline; must : roheline. Paaridena esinevad ka metallidest tuletatud värvused, nt hõbe : kuld (Hõbetõld, kuldsed naelad? - Taevas ja tähed), kuldne : vaskne (Kuldene kulp ja vaskene vars? - Rukis). Kuigi üldjuhul on nimetatud metallidel eriomane värv (nt kullal kulla värv), ei ole alati selge piir, kas mõeldud on metalli kui materjali või pigem värvust.

Tulemuslikud parallelismikolmikud on must : punane : roheline (nt Must mulk, punane pulk, roheline tutt? - Porgand); hahk: must: verev (Hahk nahkjas, must järijas ja verrev punapüks? - Täi, kirp ja lutik); kirju : valge : must (Kiri kari, valge vari, must karjane kaitseb? - Kogudus, kerik ja õpetaja).

Liitvärve tuleb mõistatustes ette haruharva, üksik näide on siinjuures 1940. aastal Karja kihelkonnast ühel korral kirja pandud helesinine tuntuima, sibula-mõistatuse variandis Eest siiruviiruline, päält kullakarvaline, äärest helesinine.

Värvileksika vaateprismast on mõistatustes huviväärne seitsmest spektrivärvist koosnev vikerkaar, mis esineb 28 mõistatustüübi (kokku 596 variandi) lahendina, olles sealhulgas tüüpide EM 1210, 1523, 1619, 1930, 1959, 1993, 2777, 2778, 2779 tiitelteksti vastus. On huvitav, et ainult kolm neist tiiteltekstidest osutavad küsimuspooles värvusele: Mitme karva viiruline, kena lindi triibuline, lähen lookes üle maa, keegi kätte mind ei saa (EM 1210), Siidilõngast siutud, kuldlõngast koetud, istub ilma harja pääl (EM 1959), Sinine siiter, punane paater, ripub rikka mehe aeda laes (EM 1993).

Kuigi vikerkaar on vaieldamatult kõige värvilisem loodusnähtus, ei aita küsimuspool vastajat värvidega. Vikerkaar võib olla lahendiks tavapäraselt paja/katla-mõistatuses (Ait all, look peal EM 12 ja Kure kael üle mere EM 821), kus rõhuasetus on pigem kaare/looga kujul. Samasugust tendentsi kohtab ka regilauludes (Jaago 1997: 60). On viidatud ka vikerkaare usundilis-mütoloogilistele kujutelmadele, mille kohaselt on vikerkaart muuhulgas peetud kahe maailma - siin- ja sealpoolsuse ühenduseks ja ka rahvausundis valitseb pigem vikerkaare kuju - kaar, köis, ammukaar, sild, vöö (Sarapik 1993). 


\section{Värvinimetused keerdküsimustes}

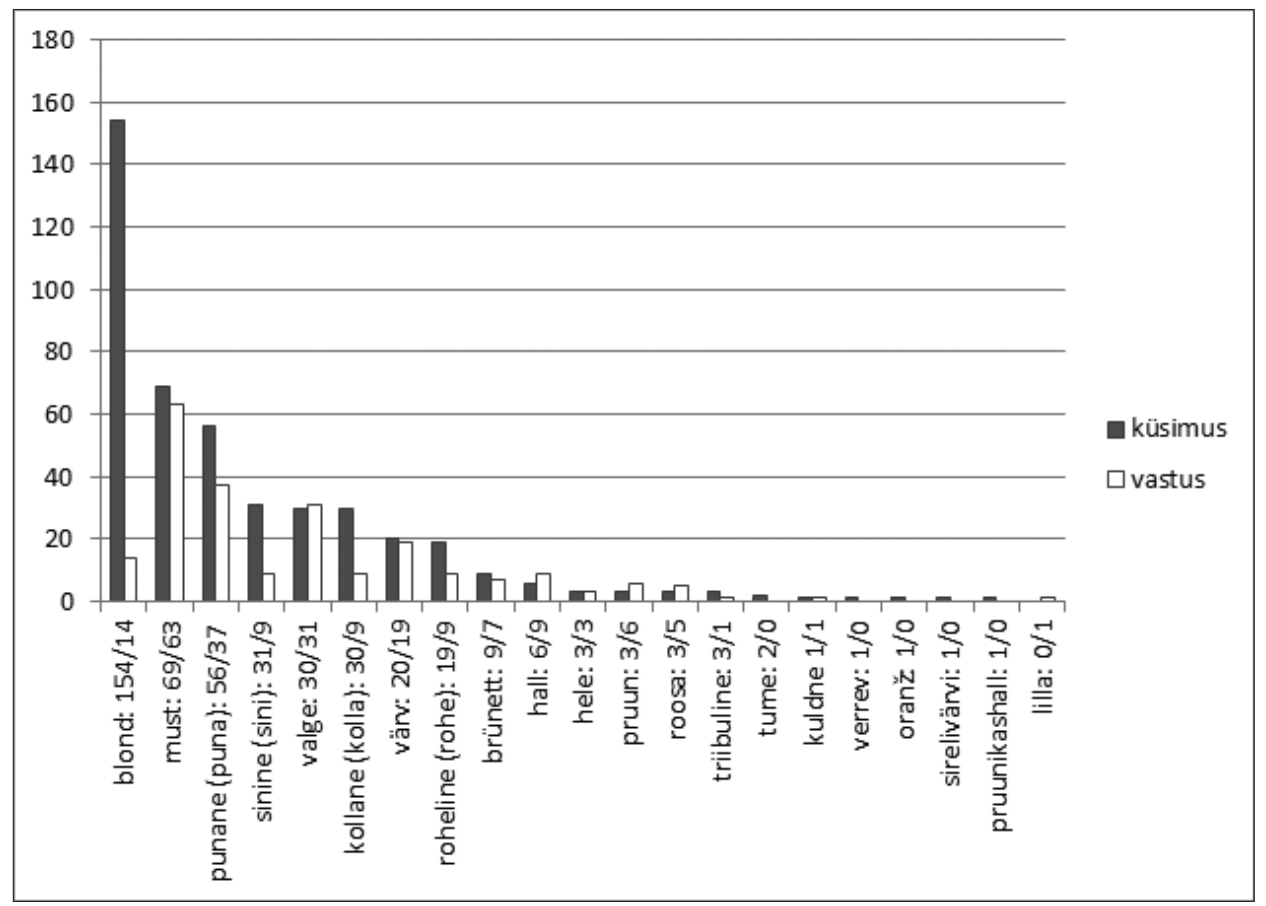

Tabel 2. Värvisõnade esinemissagedus keerdküsimuste küsimus- ja vastuspooles andmebaasi "Eesti keerdküsimused" põhjal. Otsingus arvestatud 3870 tiiteltekstist esinevad üks või enam värvinime küsimuses 443 ja lahendis 224 korral.

Nii nagu klassikaliste mõistatuste puhul, on ka keerdküsimuste värvimaailm ülimalt rikas ja kirev, samas ilmnevad alaliigi eripäradest tulenevalt hoopis teistsugused väljendused. Võrreldes klassikaliste mõistatuste värvistatistikaga on keerdküsimustes olemas kõik põhivärvinimed, kuid suure edumaaga on juhtpositsioonil heledajuukselist ja valgeverelist tähistav subjektisidus värvisõna blond ${ }^{4}$, millele järgnevad must, punane, sinine, valge, kollane jt (tabel 2). Selle olukorra taga on 1990. aastate teisel poolel küsimus-vastus-vormilistesse naljadesse saabunud uue favoriitse rahvusvahelise tegelaskuju, blondiini mõju eesti repertuaarile. 2007. aasta koolipärimuse kogumisvõistlusele laekunud üleskirjutuste hulgas moodustavad blondiini-küsimused (470 teksti, 115 tüüpi) tervelt kolmandiku kõigist kirjapandud keerdküsimustest (vt Voolaid 2010: 141-143). Andmebaasis esineb blond/blondiin ühtekokku 154 blondiininalja küsimuspooles, kusjuures populaarsemad on: 
1. Kuidas blond kala tapab? - Ta uputab kala ära. (61 varianti)

2. Miks blond kella aknast välja viskab? - Ta tahab näha, kuidas aeg lendab. (60 varianti)

3. Miks blondiin ei sõida Kiaga? - Sest tema sõbranna mobiilile on kirjutatud NOKIA. (60 varianti)

4. Kuidas ajada blondiin hulluks? - Pane ta ümarasse tuppa ja käsi nurka minna. (40 varianti)

5. Miks blondiin pead pestes kõnnib? - Sest ta kasutab šampooni "Wash and Go". (32 varianti)

6. Miks blondiin lakub kella? - Sest "tic tac" annab vaid kaks kalorit. (32 varianti)

7. Miks 17 blondi seisavad resto ukse taga ega söanda sisse minna? - Sest uksel on silt "Alla 18 sissepääs keelatud". (30 varianti)

8. Miks blond arvutit kardab? - Sest arvutil on hiir. (24 varianti)

9. Kuidas blondiin linde tapab? - Viskab kaljult alla. (18 varianti)

10. Miks blondiin peale pea pesemist ruttu ära jookseb? - Sest šampoonile on kirjutatud: "Wash and Go". (13 varianti)

Blondiiniküsimustes võivad esineda ka teised värvinimed, tähenduslik on nt punane vein: Miks blond joob julgesti enne autosõitu punast veini? - Ta arvab, et punane vein ei paista vere seest välja. (2 varianti)

Heledapäisusele viitava blondiini kõrval leidub teisigi juuksevärvi märkivaid subjektisidusaid värvinimetusi (nt brünett, punapea), kes on küsimustes targemad tegelaskujud.

Kuidas nimetatakse brünetti kahe blondiini vahel? - Tõlk

Kas sa tead, kes on punapea? - Blondiini tõlk

Kuidas kutsutakse kahe brüneti vahel istuvat blondi? - Mõttekatkestuseks

Mis vahet on brünetil ja prügikastil? - Prügikast viiakse üks kord nädalas välja.

Juhmiskripti toel toimivate blondiininaljade tagamaid on tõlgendatud mitmeti ja interpreteeritud ka psühhoanalüütilises võtmes. Saksa folkloristi Sabine Wienker-Piepho (1998: 135) väitel ülistavad blondiininaljad ilmselgelt naiste ületamatut rumalust, nagu oleks tarkus ainult meeste kaasasündinud privileeg. Blondiini kui rumala ja naiivse võrdkuju stereotüüp on sooliselt laetud sotsiaalne ja kultuuriline konstruktsioon ja on selge, et ühiskonna toimimisega seotud sotsiokultuurilised protsessid (naisküsimuse teadvustamine, naiste ühiskondliku positsiooni muutumine ja nende osakaalu kasv avalikus sfääris, soolise võrdõiguslikkuse problemaatika võimendumine 1990. aastate teisel poolel, vt ka Stanoev 2010; Oring 2003) on mõjutanud blondiininaljade sündi 
väga tugevasti. Kindlasti peegeldavad blondiininaljad reaktsioone teatud stereotüüpse iluideaali suhtes. Samas on juuksevärvil varemgi olnud kultuurilisi tähendusi, kahvatut blondi on eesti rahvausu tõekspidamiste järgi peetud halbadele mõjudele vastuvõtlikumaks, seevastu tumedaverelisi ja mõningate teiste silmatorkavate tunnustega inimesi (nt kõõrdsilmsed ja küürakad), võidi kahtlustada kaetamises või muu nõiduse toimepanemises (Hiiemäe 2012: 14).

Kuivõrd keerdküsimuste funktsioon on saada nalja eelkõige vastaja kulul, vastajat haneks tõmmata, on värvide ülesanne sageli lahendajat värvuse kui kõrvalise faktoriga õigest vastusest kõrvale juhtida. Selle väite illustreerimiseks sobib 140 variandiga keerdküsimustüüp, mille vanim üleskirjutus pärineb 1872. aasta Eesti Postimehe kalendrist ja kõlab nii: Mis saab üks must neeger, kui ta Musta merde kukub? - Märjaks. Tänapäeva globaliseerunud maailma kontekstis mõjub säärane nali rassistlikult, kuid omal ajal ilmselgelt sellised konnotatsioonid puudusid. Tüübi küsimuspooles toimub varieerumine järgmiste asendusstereotüüpide kaudu:

Mis saab neegrist, kui ta roheliselt puult kukub Punasesse merre? Neeger saab märjaks. (1936)

Milline on musta neegri valge kuub, kui ta kukub Punasesse merre? Neegri kuub on märg. (1940)

Milliseks muutub neegrist sõdur, kui ta kukub Punasesse merre? Märjaks. (1940)

Mis saab, kui neeger hüppab Punasesse merre? - Märjaks. (1985)

Mis värvi läheb neeger, kui ta Punasesse merre hüppab? - Jääb mustaks. (1992)

Mis juhtub neegriga, kes kukkus puu otsast Kollasesse merre? - Ta saab märjaks. (1992)

Missugune näeb välja mees, kes ujus Mustas meres? - Märg. (1992)

Milline on Itaalia sõdur, kui ta kukub Punasesse merre? - Märg. (1937)

Mis juhtub sõduriga, kes hüppab Punasesse merre? - Ta saab märjaks. (1992)

Madrus hüppas Musta merre, millisena ta välja tuli? - Märjana tuli madrus Mustast merest välja. (1992)

Mis juhtub hiinlasega, kui ta kukub Punasesse merre? - Saab märjaks. (1992)

Mis juhtub sõduriga, kui ta kukub Punasesse merre? - Märjaks saab. (1957)

Mis juhtub tšuktšiga, kui ta läheb Punasesse merre ujuma? - Saab märjaks. (1992) 
Kuis on musträästas, kui ta Valgjärve kukub? - Lige. (1902)

Missuguseks saab kivi, kui ta kaevu visatakse? - Märjaks. (1939)

Mis siis sünnib kiviga, kui teda Ülemiste järve visata? - Saab märjaks. (1925)

Mis juhtub valge jä̈̈karuga, kui see kukub Punasesse merre? - Märjaks saab. (1992)

Selles tüübis võib vabalt varieeruda nii etniline subjekt kui ka veekogu. Näib, et värvinimesid sisaldavad veekogud on kõnekamad ja mõjusamad kui nt kaev või Ülemiste järv. Salakaval küsimus iseloomustab suuresti kogu keerdküsimuste žanrit ja põhineb esmajoones pragmaatikast tuntud Paul Grice’i formuleeritud suhtlemisreeglite ehk maksiimide rikkumisel. Rikutakse niisiis järgmisi reegleid: 1) kvaliteedi maksiim: anna tõest infot; 2) kvantiteedi maksiim: anna infot parasjagu nii palju, kui vaja; 3) relevantsuse maksiim: anna ainult infot, mis on oluline; 4) meetodi maksiim: anna infot parimal võimalikul viisil (Grice 1991: 28). Küsimuses on täidetud kvaliteedi (edastatakse eeldatav tõene info - X kukkus merre), kvantiteedi (on teada, et X kukkus merre) ja relevantsuse maksiim (oluline on, et X merre kukkus), kusjuures täpsustav määratlus, nt must (neeger), Itaalia (sõdur), valge (jääkaru) või Must, Punane, Kollane meri, võib olla eksitava tähendusega ja vastaja mõtted mujale juhtida. Rikutud on meetodi maksiim (küsimus Mis sai X-st või Mis juhtus X-ga eeldab vastajalt mõtete juhtimist millelegi traagilisemale kui lihtne konstateering, et iseenesest mõista sai neeger/sõdur/tšuktši... veega kokku puutudes märjaks. Sageli võib sedasorti küsimustes täheldada tautoloogiaid: liialdava loogikaveana mõjub juba vanimaski üleskirjutuses figureeriv must neeger, kuivõrd konkreetse rassi esindaja ongi tumeda- või mustanahaline.

Analoogse näitena võib tuua keerdküsimuse Mikspärast kandis Napoleon punaseid püksitrakse? Sellepärast et püksid üleval seisaksid, mille küsimuspooles on rõhk (punasel, aga selle asemel ka nt kollasel või mõnel muul) värvusel justkui olulisimal omadusel, mis ärgitab vastaja mõtteid, kuid osutub vastuse seisukohast täiesti kõrvaliseks. Taas on siin täidetud kvaliteedi maksiim (Napoleon kandis punaseid püksitrakse). Nihked toimuvad juba kvantiteedi maksiimis (värvi mainimine on üleliigne info ja viib vastaja mõtted mujale, seda võib võimendada intensiivne punane värvitoon), relevantsuse maksiimis (punane ei ole üldse oluline) ja meetodi maksiimis (küsimuses kerkib esile punane värvus, mis viib vastaja püksitrakside esmaselt funktsioonilt - neid kasutatakse pükste ülalhoidmiseks - mingite muude funktsioonide otsimisele).

Omaette vanema ainekihistu moodustab keerdküsimuste allrühm Kas võtad? / Kumma võtad? algusega küsimused, milles on sarnasusi klassikaliste 
mõistatuste metafoorse poeetikaga. Ka neis võib värvus olla metafoorses kujundis, sagedamini esindatud värvipaarid on sinine : punane ja punane : sinine:

Kas lähed sinist silda mööda või punast purret mööda? - Taevasse või põrgu.

Kas võtad punase pulli või sinise sitika? - Maasikas, sinikas.

Kumba sa võtad, sinise rätiku voi punase palaka? - Taevas, põrgu.

Kas sa võtad puu otsas punast või silla päält sinist? - Puu otsas lind, silla päält rooja.

Niisamuti on punane : must

Kas võtad punast pulka või musta mulku? - Punast pulka, siis saan porgandi.

Punane : kollane

Kas sa võtad posti otsast punast või kivi pääld kõllast? - Posti otsas lipp, kivi pääld rooja.

Roheline : must

Kas sa võtat pika ja rohilise või lühikese ja musta? -Pikk ja rohiline = kask, lühike ja must = kuusk.

Hall : valge

Kas sa võtat halli hännälise või valge puolise? - Hall hännäline = kass, valge puoline $=$ luik

Kuldne : kollane

Kumba sa võtad, kas kuldteki voi kollase rätiku? - Päike, kuu.

Valge : roosa

Kas sa võtad katussest valged või maa pääld roosad? - Katussel tuike ja maa pääl tuli.

Iseäranis palju esineb värvuste rakendamist Mis on? algusega rahvusvahelistes ja seeriatena levivates absurdimaigulistes küsimustes. Huumoriuurija Emil Draitseri (1998: 21) järgi on tegu traditsiooniliste Armeenia mõistatuste vormiga. Absurdsete küsimuste ja täiesti ettearvamatute vastustega Armeenia mõistatuste valvenäiteks toob E. Draitser mitmest küsimusest koosneva dialoogi, mida tuntakse meilgi. Mis on roheline, ripub laes ja piiksub? - ? - Heeringas. - Miks roheline? - Minu heeringas, võin ta ükskõik milliseks värvida. - Aga 
miks ta laes ripub? $?^{5}$ - Minu heeringas, võin ta ükskõik kuhu riputada. - Aga miks ta piiksub? - Selle üle olen isegi imestunud (Draitser 1998: 21). Draitseri järgi panid just need mõistatused aluse hilisematele põhiliselt poliitilisi, etnilisi ja erootilisi teemasid käsitlevatele Armeenia raadio küsimustena ("Armeenia raadiolt küsitakse ... Armeenia raadio vastab") tuntud seeriatele, mis said Venemaal populaarseks 1950. aastatel, Stalini-järgsel sulaperioodil. Ei raadio ega Armeeniaga polnud neil küsimustel õigupoolest mingit pistmist. Selliseid absurdiküsimusi tuntakse ka Eestis hästi, neid laekus rohkelt nii 1992. aastal kui ka 2007. aastal toimunud üle-eestilise koolipärimuse kogumisvõistluste tulemusena. Ulla Lippose (1995: 210-211) järgi saavad mõistatused laiemalt peamist inspiratsiooni loodusest ja kodusest argimaailmast, mille kõrval asub absurdimaailm, kus elavad "värvikad vigurdajad" (värikkäät viipottajat). Lipponen nimetab ka absurdiloome neljanda mõõtme ehk olendid, keda tavaelus ei eksisteeri, kuid küsimuspooles kuvatakse vastajale mingil omapärasel, reaalsuses võimatul moel. Absurd tekib tõe- ja absurdimaailmade kokkupõrkel ja kohatisel kattuvuselgi, kusjuures oluline mänguline element on neis just värvus. Alljärgnevates näidetes on inimlikes situatsioonides köögiviljad tomat ja kapsas.

Mis on punane ja liigub üles ja alla? - Tomat liftis. - Mis on punane ja ootab rohelist? - Tomat tahab üle tänava minna.

Mis on roheline ja lendab taevas? - Suvepuhkusele minev kapsas. - Aga mis on pruun ja lendab taevas? - Suvepuhkuselt tulev kapsas.

Selliste Mis on? küsimuste taga võivad eksisteerida ka mingid reaalsed olukorrad, nt

Mis on keskelt punane, ümbert karvane? - Koerakari ümber Punase väljaku.

Värviteema aitab kaasa ka mitmemõtteliste seoste tekitamisele, alljärgnevas küsimuses on soov vastajat ilmselgelt erootilistele mõtetele juhtida:

Mis on punane, umbes $12 \mathrm{~cm}$ pikk, ripub, mõnel on ja mõnel pole? - Vene 10-rublane.

Mitmesuguseid värviseoseid kohtab absurdsetes rahvusvaheliselt tuntud elevandiküsimustes, mis on tervete omaette teematsüklitena rohkelt esindatud nii 1992. kui ka 2007. aasta koolipärimuse suurkogudes. Need said alguse 1960. aastate alul Ameerika Ühendriikides, kus elevandinaljad (elephant jokes) kuulusid 17-20aastaste noorte repertuaari, moodustades Ameerika linnafolkloori (poploori) olulise osa (elevandiküsimuste kui zooabsurdse huumori kohta 
vt põhjalikumalt Voolaid 2008: 28-30). Elevandinaljad põhinevad kuulajate eksiteele viimisel, ebaloogilisel järeldusel või vastuoludest tuleneval situatsiooni absurdsusel (antropomorfiseeritud loomakujul). Just nimelt absurdsuse väljendamisel on värvidel suur roll. Eesti elevandiküsimuste hulgas (u 950 teksti, 84 tüüpi) on levinuim tüüp, milles mänguliselt kasutatakse värvinimesid, 76 üleskirjutusega Miks on elevandil sinised sokid? - Sest punased said märjaks. - Miks on elevant vannis selili? - Et sinised ka märjaks ei saaks. Algküsimuse sokivärv ei ole fikseeritud, vaid vabalt asendatav, nii kohtame ka nt variante punased / rohelised / kollased / hallid / triibulised sokid; punased / rohelised sukad; roosad tennised.

Enim kasutust leiab elevandiküsimuste värvipaletis punane (elevandiküsimuste koguhulgas 119 korral), järgnevad roosa (40 korral), sinine (40 korral, sh ühel korral helesinine), kollane ja roheline (mõlemad 17 korral), hall (15 korral), must ( 7 korral) ning valge (6 korral).

Miks on elevandil punased silmad? - Et kirsipuu otsast välja ei paistaks. - Aga kas olete kunagi näinud elevanti puu otsas? - Ei ole. - Miks? ? - Hästi peidab ennast. (54 varianti)

Kuidas me teame, et kaks elevanti on vanas Zaporožetsis? - Aknad on hallid. (6 varianti)

Mis vahe on elevandil ja ploomil? - Elevant on hall. - Mida ütles Jane Tarzanile, kui nägi elevante üle mägede tulemas? - "Tarzan, vaata - ploomikari tuleb üle mägede." - Miks Jane ei teinud elevantide ja ploomide vahel vahet? - Sest Jane oli värvipime. (4 varianti)

Miks on elevant suur, hall ja kortsuline? Sest kui ta oleks väike, valge ja sile, oleks ta aspiriin. (3 varianti)

Elevant kui naljaküsimuste koomiline metafoor on rohkelt tõlgendamist leidnud, nt maagilise jõu ja tugevuse sümbolina (Boskin 1997: 62). Psühhoanalüütilise koolkonna uurijad on elevandinaljade sündi 1960. aastate Ameerika kontekstist lähtuvalt põhjendanud mustanahaliste kodanikuõiguste aktualiseerumisega, kuivõrd korpulentse elevandi hele nahavärv pakkus kontrasti tumedale nahavärvile, saades nõnda peidetud võitlusvahendiks mustade mõjuvõimu kasvu vastu, kajastades valgete hirme mitmete mustadele omistatud stereotüüpiliste omaduste (nt kõrgem potents) ees (vt Dundes \& Abrahams 1987).

Kahe plaani (hele-tume, suur-väike) opositsioon on huumori loomevõttena väga levinud. 1992. aasta koolipärimuse kogumisaktsiooni käigus jõudsid arhiivi nn neegri- ja hiinlaseküsimused, milles esildub värvus rassitunnust väljendava nahavärvina. Neegriküsimuste jadades (samuti hiinlaste küsimuste seerias) on näha järgnevusstruktuuri, kus esimeses lülis määratletakse situat- 
siooni füüsiline välispilt (Mis on must ja ühe jalaga? - Ühe jalaga neeger), teises lülis määratakse n-ö petlik arengusuund (Mis on must ja kahe jalaga? - Kaks ühe jalaga neegrit) ning kolmandas lülis saabub puänt, mis on vastuolus teises lülis väljapakutud arengusuunaga (Mis on must ja kolme jalaga? - Klaver). Sellist võtet kohtab ka kolmarvule rajatud tavaanekdootides (nt nn kolme rahva lugudes) ja kogu folkloorses narratiivis üldse. Neegriküsimustes on nahavärv element, millele saab üles ehitada valge-musta, musta-sinise vastanduse, üldistavalt öeldes on siin tähtis värvigamma hele-tume opositsioon. Analoogne mehhanism toimib hiinlaste küsimustes (Mis on kollane ja roomab? - Hiinlane otsib miini. - Mis on kollane ja lendab? - Hiinlane leidis miini), kus rassilise omadusena on oluline osa kollasel nahavärvil. Seetõttu esinebki eesti materjalis vahel hiinlase asemel teisi sama rassi esindajaid, nt vietnamlasi ja jaapanlasi. Praeguses globaliseeruvas ühiskonnas tunduvad seesugused, kohati sadistliku maiguga etnilised küsimused rassistlike, solvavate ja sobimatutena, kuid oma leviku kõrgajal (Eestis 1980. ja 1990. aastail) kandsid need ilmselt kauge eksootilise "teise" ülimalt lihtsustatud kuvandit. Paralleele saab siin tõmmata omaaegsete ülipopulaarsete tšuktšinaljadega, mis algselt olid Venemaal etniliselt markeeritud, kuid omandasid mujale levides tegelikkusest irdunud anekdootliku tüüpkuju funktsioonid (vt Tuisk 1997: 20), mistõttu ei käsitletagi tšuktšisid alati mingi kindla rahvusrühma esindajatena.

Keerdküsimustes võib täheldada ka värvidele omistatavaid üldisemaid kultuurilisi tähendusi. Olgu siis must kui leinavärv (Miks on kirbud mustad? - Neil on leinamine oma suguvösa pärast. Varaseim eesti tekst on toodud Nörmanni Aeawitjas 1868) või punane teatud kohalikus sotsiokultuurilises kontekstis nõukogude poliitilise meelsuse sümbol (Kas NL-is oli rassivastuolusid? - Ei olnud, sest puudusid nii mustad kui valged - kõik olid punased). Need värvide tähendused võivad väljendada ka tähelepanekuid kindla aja ja suundumuse kohta, nt 2007. aasta koolipärimuse hulgas oli küsimus Kes tuleb valge kasukaga? - Uusrikas. 


\section{Värvinimetused piltmõistatustes}

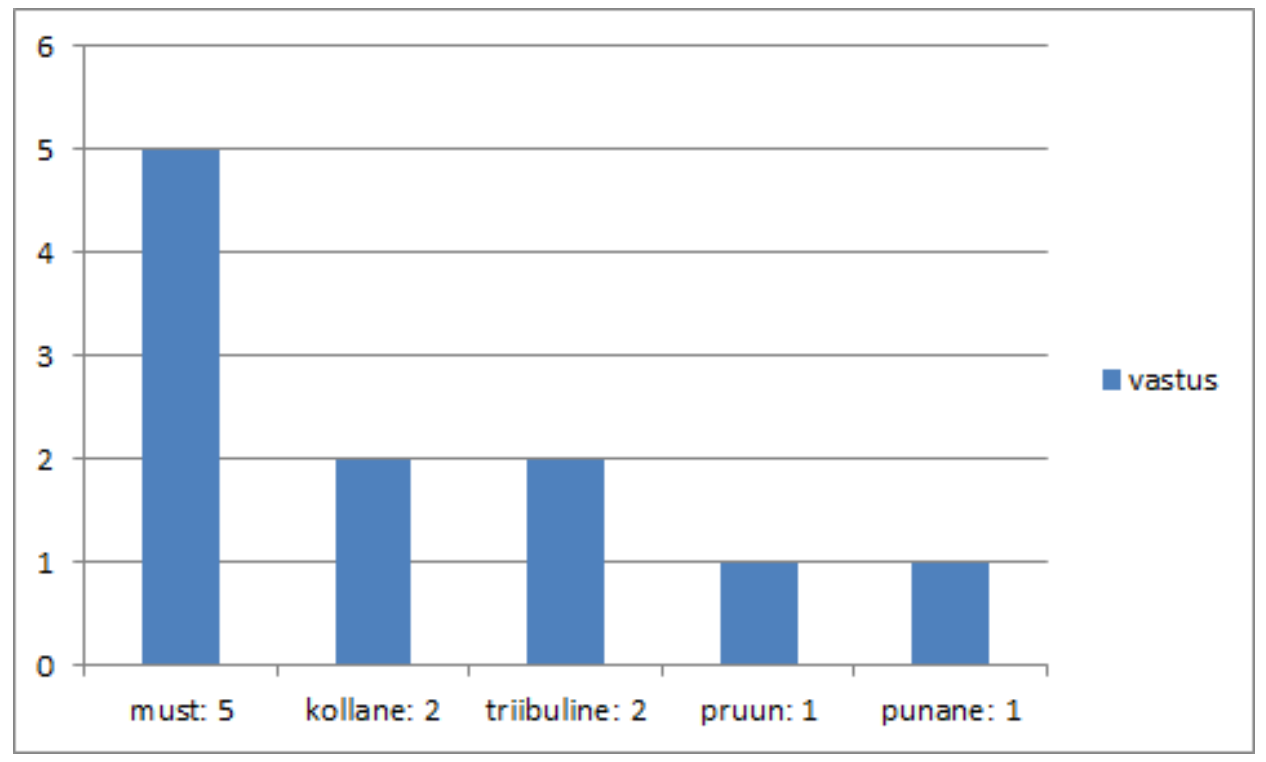

Tabel 3. Värvinimetused piltmõistatuste vastuspooles andmebaasi "Eesti piltmõistatused" põhjal, otsingus arvestatud 803 tiiteltekstist esineb värvinime 11 korral.

Uuema mõistatusmaterjali hulka kuuluvad piltmõistatused ehk reebused meenutavad olemuselt tavamõistatusi, kuivõrd kirjeldavad midagi (küll mitte verbaalsete, vaid graafiliste vahendite abil), millele lahendusnõude juurdelisamine on vaikimisi endastmõistetav. Tiiteltekstides on sagedustabelis (tabel 3) esikohal must (viies tiiteltekstis), millele järgnevad kollane, kahe värvi vahelduvkooslust markeeriv triibuline (kahes tiiteltekstis) ning pruun, punane ja valge (ühes tiiteltekstis).

Ka piltmõistatuste hulgas on rohkesti selliseid, mis rajanevad ühe või teise rahvuse/rahvastikurühma iseloomulikul atribuutikal (mehhiklased, neegrid, indiaanlased, grusiinid, kauboid jne). Esindatuse poolest kuulub eesti piltmõistatustes väärikaim koht kauboile (nt Kauboi sõidab jalgrattaga), kuid palju leidub just nahavärvusest lähtuvaid piltmõistatusi. Nii nagu keerdküsimustes, nii on sellised emblemaatilised kujundid ka piltmõistatustes nt neegri tume ja hiinlase kollane nahavärv. Taas kohtame must-valge-vastandust, nt 


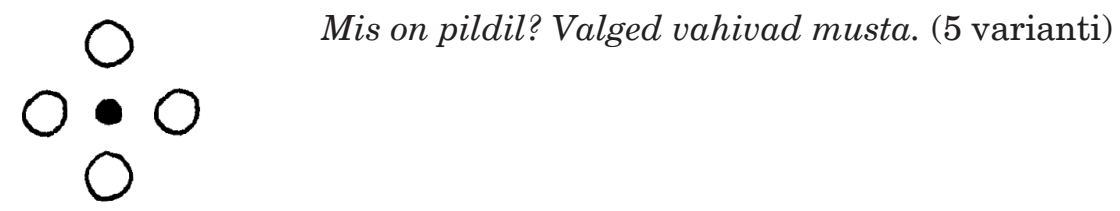

Lisaks on mustale orienteeritud mitmed kaudselt selle värvusega seotud subjektid, nagu mustlane või mustkunstnik:
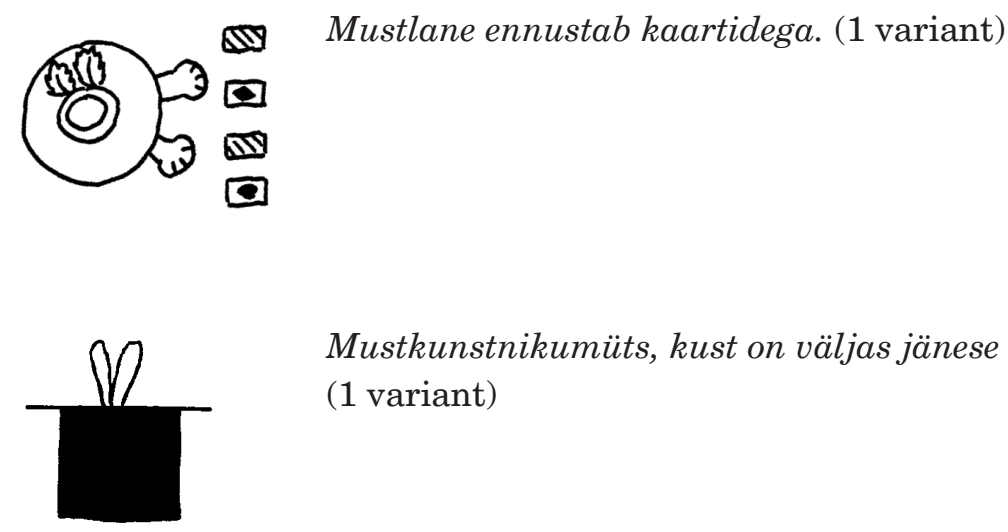

Mustkunstnikumüts, kust on väljas jänese kõrvad.

(1 variant)

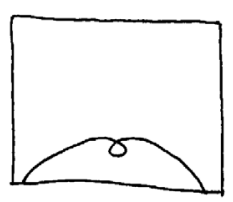

Mustanahaline teeb spagaati. (1 variant)

Niisiis on piltmõistatuste kujundiloome äärmiselt lennukas, üks kriips võib tähendada mida tahes. Nii on ka värvikasutus selles žanris väga improvisatoorne, etteaimamatu ja loominguline. Must kast võib olla seotud väga erinevate vastuseversioonidega, millest levinumad on näiteks:

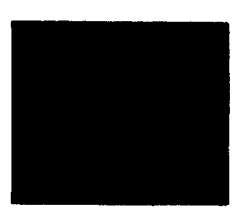

Kaks / kolm / neli / viis / seitse neegrit / mustanahalist pimedas toas.

Neli neegrit otsivad pimedas toas musta kassi.

Neegrid Mustas meres.

Neeger sööb pimedas ruumis kinnisilmi mustsõstraid.

Must kass kottpimedas koridoris.

Musta kassi öösel ei näe. 
Paljudel juhtudel ilmneb pildikirjeldusteski tautoloogiline versioon must neeger. Valge on ainult ühes eespool nimetatud tiiteltekstis vastusena Valged vahivad musta, kuid esineb mitmete tüüpide allvariantides.

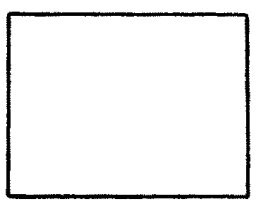

Valge hani Valges meres.

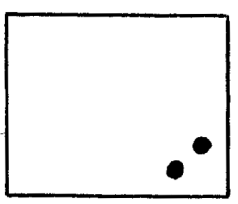

Punapead ujuvad Valges meres.

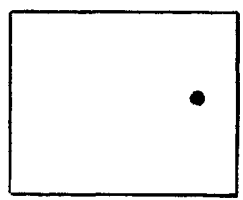

Mis on pildil? Kirp valge voodilina peal.

Värvus must on esindatud ka ühes narratiivses piltmõistatuses, kus küsimuspoole moodustab pikem jutt, millele peab vastaja lahenduse leidma.

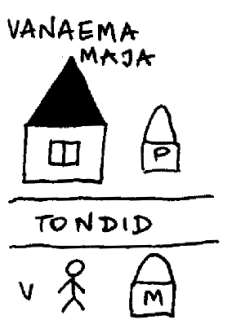

Kuidas vanaisa saab vanaema juurde? - Vanaisa kastab ennast musta veega, tondid arvavad siis, et ta on ka tont, vanaema maja juures kastab end puhta veega üle. 


\section{Kokkuvõtteks}

Värvuste kasutamine mõistatuste eri alaliikides on oluline ja paljufunktsiooniline võte. Kuna klassikalise mõistatuse kujundis kajastub enamasti lahendobjekti välimus, selle meeleliselt tajutavad küljed, osalevad värvinimed mõistatuste kujundiloomes kõige otsesemalt. Sealjuures on olulised poeetiline heakõla (alliteratsioon) ja parallelism (vastandused, värvipaarid, -kolmikud, pikemad loetelud). Värvuste sageduspingerida juhivad eesti keele põhivärvinimed (must, valge, punane, hall jt), klassikalistes mõistatustes ei esine eesti põhivärvinimedest lillat ega oranži. Mõistatuste arhailisele keelele viitab asjaolu, et rohelise kõrval on levinud haljas, murdelised hahk ja harm, kollase kõrval kuldne.

Klassikalistes mõistatustes abistavad värvused vastajaid. Värvused kirjeldavad lahendobjekti välistunnuseid metafoorsetes ülekannetes väljakujunenud kinnisklišeede struktuurielemendina. Määratletud subjektiga tekstides, kus tervikkujund langeb kokku kirjeldava lause süntaktilise alusega, on subjektiks sageli zootermin, mille juures mängib täiendina olulist rolli värvus (nt hall/ must /valge härg; must siga ja punased põrsad). Ilmneb universaalne suundumus, et suured heledad loomad ( hall / valge härg; valge hobune) viitavad mingile suurele, suhteliselt raskele või väheliikuvale objektile (nt kivi, veski, kirik, jalad, heinakoorem), must härg seostub aga mingi töövahendi (sepalõõts, aidavõti) või tegutseja tunnusliku välimuse ja tugeva häälega (õpetaja kantslis jutlust pidamas). Värvus on oluline ka metonüümsetes ja metafoorsetes inimkujundeis (nt must mees, punane poisike). Mõningail juhtudel esinevad need kujundid kindlates sõnajärjendites (nt hani haljas, kuid mitte kunagi haljas hani).

Määratlemata subjektiga tekstides, kus mõistatatav objekt esitatakse tegevuste, omaduste, suhete, kohtade, aegade vms kaudu, rakendatakse värvinimesid mingitel paradoksaalsetel erinevustel või vastuoludel põhinevates süntaktilistes vormistereotüüpides ( nt Alt/seest ..., pealt ...; Pealt ..., alt / seest ...; Eest ..., tagant/otsast ...; Enne / esite ..., pärast ...).

Huumorile keskendunud keerdküsimuste ja piltmõistatuste värvimaailm on samuti kirev. Klassikaliste mõistatustega sarnases troobiloomes esineb värvinimesid vanemas ainekihis, nt Kas võtad? / Kumma võtad? algusega küsimustes. Siiski väljendatakse keerdküsimustes värvuste kaudu ka kultuuristereotüüpe ja sümboleid. Võrreldes klassikaliste mõistatuste värvistatistikaga on keerdküsimustes juhtpositsioonil heledajuukselist ja valgeverelist tähistav subjektisidus värvisõna - substantiiv blond (millest on kujunenud naljades rumala sünonüüm), põhjuseks 1990. aastate teisel poolel populaarseks saanud juhmi-skriptil põhinevate blondiininaljade rohkus. Värvidel on tähtis roll 
Mis on? algusega absurdiküsimustes, samuti rahvusvaheliselt tuntud etniliste naljaküsimuste ja absurdsete elevandiküsimuste seeriates, kus kahe plaani (hele-tume, suur-väike) opositsioon on huumori loomevõttena viljakas. Värvide roll seisneb sellisel juhul realistliku maailmapildi nihestamises, tegelikkuse kõverpeeglis tekib huumori esiletulekuks tarvilik üllatusmoment. Keerdküsimuste funktsioon on sageli vastaja kulul nalja saada, mistõttu on mõningatel juhtudel värvide ülesanne lahendajat hoopis värvuse kui võimsa visuaalse kõrvalise faktoriga õigest vastusest eemale juhtida. Selles alaliigis on esiplaanil retooriline, anekdoodi olemusega sarnanev võte, kus küsija annab küll kuulajale-vastajale aega vastuse üle mõelda, kuid vastab pärast lühikest pausi ise.

Piltmõistatustes on värvikasutus etteaimamatu ja loominguline, kuid sarnaselt keerdküsimustega toetavad värvid neis teatud klišeid ja stereotüüpe. Taas on värvid rakendatud etniliste stereotüüpide loomesse, kus on levinud nt valge-musta opositsioon.

Käesolevas artiklis on fikseeritud mõistatuste värvisõnavara üldtendentsid, kuid mitmed tahud (nt saab mõistatustes esinevaid värvusi käsitleda metafooriteooriate kaudu, ka värvide sümboltähendused ja sotsiokultuurilised tagamaad) väärivad tulevikus põhjalikumat analüüsi.

\section{Tänuavaldus}

Uurimus on seotud Eesti Teadusagentuuri institutsionaalse uurimisprojektiga IUT 22-5, seda toetas Euroopa Liit Euroopa Regionaalarengu Fondi kaudu (Eesti-uuringute Tippkeskus - CEES). Autori eriline tänu kuulub artikli anonüümsetele retsensentidele kõigi asjakohaste märkuste-soovituste eest. 


\section{Kommentaarid}

1 Maailmapildi tõlgendamist mõistatuste kaudu tuli esile hiljemgi. 1981. aastal ajakirja Looming korraldatud vestlusringis selgitas Mikk Sarv eestlaste maailmapilti ühe mõistatustüübi abil. Tüübi EM 367 vanim tekst Isa pitk, ema lai, õde sõge, vend on pöörane (Der Vater lang, die Mutter breit, die Schwester blind, der Bruder verkehrt), mille lahenduseks on maailm, pärineb Anthon Thor Helle 1732. aastal ilmunud grammatikast. Pikk isa on taevas, lai ema on maa, pime õde on öö, pöörane vend on päev. Seosed tekivad sellest, et samal mõistatusel on ka teisi lahendeid peale maailma. Kui lahendiks on humal, siis on pikk isa humalavars, lai ema tema lehed, pimedaks õeks võrsed ja väädid, pööraseks vennaks käbid ja viljad. Kui lahendiks on kuusk, siis pikk isa on kuusetüvi, lai ema on kuuseoksad, lapsed on käbid. Kõigis variantides nimetatakse omadusi, nagu pikkus, laius, pimedus ja pöörasus, samuti nelja perekonnaliiget: isa, ema, tütart ja poega. Nõnda teeb Mikk Sarv järelduse, et eestlase maailm oli pikk, lai, pime ja pöörane (vt ka Ernits jt 2015: 73).

2 17. sajandil hakkas haljas (tähenduses 'roheline') taanduma sõna roheline ees. Sõna roheline varaseim kasutus esineb Heinrich Gösekeni 1660. aasta grammatikas (Sutrop 1996: 226). On põnev kokkusattumus, et samas teoses on trükitud ka kolm varaseimat eesti mõistatuse kirjapanekut.

3 Näitetekstide keelepilt on siin ja edaspidi esitatud originaalipäraselt.

4 Blond on neis naljades subjektisidus lihtsõnaline värvinimi (vt Oksaar 1961), mida kasutatakse juuste, nahavärvi jne kohta, kuid tegu on nimisõnalise, mitte tavapäraselt omadussõnalise värvinimega.

5 Varaseim eesti tekst koos kontekstilise lisandusega on talletatud arhiivi 1955. aastal Tartust: Mis see on? Ripub laes, on roheline ja piiksub? - See on heeringas. - Kuidas nii? - Ma riputasin ta lakke ja värvisin roheliseks. - Aga ta ei piiksu ju! - Noh, selle ma ütlesin niisama juurde, et sa nii kergesti ära ei arvaks. See oli praktilises esituskavas tihti nagu mingiks avamõistatuseks, sest see oli nii üldtuntud, kõik seda teadsid ja taipasid, et nü̈̈d hakatakse esitama armeenia mõistatusi. (RKM II 209, 606 (13)) 


\section{Kirjandus}

Boskin, Joseph 1997. Rebellious Laughter: People's Humor in American Culture. Syracuse University Press.

Draitser, Emil A. 1998. Taking Penguins to the Movies: Ethnic Humor in Russia. Detroit: Wayne State University Press.

Dundes, Alan \& Abrahams, Roger 1987. On Elephantasy and Elephanticide. Dundes, Alan. Cracking Jokes: Studies of Sick Humor Cycles and Stereotypes. Berkeley, California: Ten Speed Press, lk 41-54. [Esitrükk 1969 Psychoanalytic Review 56, lk 225-241.]

EM I = Hussar, Anne \& Krikmann, Arvo \& Saukas, Rein \& Voolaid, Piret (koost), Krikmann, Arvo \& Saukas, Rein (toim) 2001. Eesti mõistatused I: Monumenta Estoniae Antiquae IV:1, 1-1350. Tartu: Eesti Keele Sihtasutus.

EM II = Hussar, Anne \& Krikmann, Arvo \& Saukas, Rein \& Voolaid, Piret (koost), Krikmann, Arvo \& Saukas, Rein (toim) 2002. Eesti mõistatused II: Monumenta Estoniae Antiquae IV:2, 1351-2800. Tartu: Eesti Keele Sihtasutus.

Ernits, Enn \& Sarv, Mikk \& Tedre, Ülo \& Kõiv, Madis \& Lõugas, Vello \& Vint, Tõnis \& Viires, Ants \& Stöör, Ülo \& Eelsalu, Heino 2015 [1981]. Värvid, arvud, kujundid: Esivanemate maailmapildist. Mäetagused 61, lk 69-80 (http://dx.doi.org/10.7592/ MT2015.61.pilt).

Grice, Paul 1991. Studies in the Way of Words. Cambridge, Massachusetts, London: Harvard University Press.

Hiiemäe, Reet 2012. Kaitsemaagia eesti rahvausundis. Tallinn: Pegasus.

Jaago, Tiiu 1997. Mis seal tõuseb, soost sinine, soost sinine, maast punane? Sinise ja punase võimalikust tähendusest regilaulus. Mäetagused 5, lk 54-72 (http://www.folklore. ee/tagused/nr5/pdf/tiiu.pdf - 10. juuli 2016, doi:10.7592/MT1997.05.tiiu).

Jaago, Tiiu 2016. Punane regilaulus: sõnad ja vormelid. Mäetagused 64, lk 9-34 (http:// dx.doi.org/10.7592/MT2016.64.jaago).

Krikmann, Arvo 1997. Sissevaateid folkloori lühivormidesse I: Põhimõisteid, žanrisuhteid, üldprobleeme. Tartu: Tartu Ülikooli Kirjastus (http://www.folklore.ee/ kriku/PARINTRO/Parintro.pdf - 20. juuli 2016).

Krikmann, Arvo 1999. Vanasõnad loomade identiteedist (Tüpoloogilisi memuaare). Mäetagused 12, lk 52-86 (http://folklore.ee/tagused/nr12/elukad.htm - 10. juuli 2016; doi:10.7592/MT1999.12.elukad).

Krikmann, Arvo 2000jj. Eesti mõistatuste kujunditest (http://www.folklore.ee/ kriku/ PARINTRO/troobid.htm - 10. juuli 2016).

Krikmann, Arvo \& Krikmann, Jaak 2012. Eesti mõistatused (http://www.folklore.ee/ moistatused - 10. juuli 2016).

Kõiva, Mare 2016. Loitsude värvimaailm. Konverents "Suur maalritöö: keelest ja meelest": Urmas Sutrop 60. 7. juunil Eesti Kirjandusmuuseumis. Ajakava ja teesid. Tartu: EKM Teaduskirjastus, lk 5 (http://www.folklore.ee/rl/fo/konve/2016/suurmaalritoo/teesid. pdf - 15. juuli 2016). 
Lipponen, Ulla 1995. Jauhot suuhun. Arvoitusvitsejä ja kompakysymyksiä. Helsinki: Suomalaisen Kirjallisuuden Seura.

Nörmann, H. Ch. 1868. Aeawitja: [Jutud ja anektoodid]. Tallinn: Linforsi pär.

Oksaar, Els 1961. Über die Farbenbezeichnungen im Deutsch den Gegenwart. Muttersprache: Band 71, lk 207-220.

Oring, Elliott 2003. Engaging Humor. Urbana and Chicago: University of Illinois Press.

Roll, Tiiu 1985. Värvinimetused ja nende kujundiline osa regivärsilises pulmalaulus. Töid eesti filoloogia alalt. TRÜ Toimetised. Tartu: Tartu Riikliku Ülikooli Kirjastus, lk 34-56.

Sarapik, Virve 1993. Vikerkaar, värv ja teadusmütoloogia. Kõiva, Mare (toim). Eksperimentaalne folkloristika. Tartu: Keele ja Kirjanduse Instituut, Kirjandusmuuseum, lk 54-55.

Sarapik, Virve 1997. Red. The Colour and the Word. Folklore: Electronic Journal of Folklore 3, lk 72-92 (http://haldjas.folklore.ee/folklore/vol3/red.htm - 10. juuli 2016; doi: 10.7592/FEJF1997.03.red).

Sarv, Mikk \& Sarv, Tõnn 1979. Loomise lugu. Eesti Loodus 7, lk 449-452.

Stanoev, Stanoy 2010. Dumb Blondes and Democracy. Folklore: Electronic Journal of Folklore 46, lk 43-60 (http://www.folklore.ee/folklore/vol46/stanoev.pdf - 15. juuni 2016; doi: 10.7592/FEJF2010.46.stanoev).

Sutrop, Urmas 1996. Värvisõnad: ääremärkusi Taani hindamisraamatu Eestimaa lehtede kohta. Keel ja Kirjandus 4, lk 225-229.

Sutrop, Urmas 2011. Eesti keele põhivärvinimed. Uusküla, Mari \& Sutrop, Urmas (koost, toim). Värvinimede raamat. Töid antropoloogilise ja etnolingvistika vallast 5 . Tallinn: Eesti Keele Sihtasutus, lk 65-88.

Sutrop, Urmas 2016. Värvinimed ja värvid vendade Grimmide muinasjutu "Lumivalguke" variantides. Mäetagused 64, lk 57-68 (http://dx.doi.org/10.7592/MT2016.64.sutrop).

Toomeos-Orglaan 2016. Mis värvi on muinasjutt? Mäetagused 64, lk 35-56 (http://dx.doi. org/10.7592/MT2016.64.toomeos-orglaan).

Tuisk, Astrid 1996. Elevant rahvapärimuses - suuline ettekanne 40. Kreutzwaldi päevade teaduslikul konverentsil 20. dets. 1996 (käsikiri autori valduses).

Tuisk, Astrid 1997. Etnilised naljad eesti laste pärimuses. Bakalaureusetöö. Tartu: Tartu Ülikooli eesti ja võrdleva rahvaluule õppetool.

Viires, Ants 1983. Eestlaste värvimaailm. Keel ja Kirjandus 6, lk 291-302.

Voolaid, Piret 2002. Eesti piltmõistatused. Tartu: Eesti Kirjandusmuuseum (http://www. folklore.ee/Reebus - 10. juuli 2016).

Voolaid, Piret 2004. Eesti keerdküsimused. Tartu: Eesti Kirjandusmuuseum (http:// www.folklore.ee/Keerdkys - 10. juuli 2016). 
Voolaid, Piret 2008. Zoofolkloorseid aspekte eesti keerdküsimustes, liitsõnamängudes ja piltmõistatustes. Mäetagused 40, lk 25-50 (http://www.folklore.ee/tagused/nr40/voolaid. pdf - 10. juuli 2016; doi:10.7592/MT2008.40.voolaid).

Voolaid, Piret 2010. Mõistatusžanri uuemaid arengusuundi 1992. ja 2007. aasta koolipärimuse kogumisvõistluse taustal. Kalmre, Eda (koost ja toim). Tulnukad ja internetilapsed. Uurimusi tänapäeva laste- ja noortekultuurist. Tänapäeva folkloorist 8. Tartu: EKM Teaduskirjastus, lk 125-161.

Wienker-Piepho, Sabine 1999. Kurjad keeled sugupooli käsitlevates naljades. Mäetagused 9, lk 133-145 (http://www.folklore.ee/tagused/nr9/blond.htm - 10. juuli 2016; doi:10.7592/ MT1999.09.blond).

\section{Summary \\ Colour terms and colour symbols in the subgenres of Estonian riddles}

\section{Piret Voolaid}

Keywords: classical riddles, colour names, colours, compound puns, conondrums, droodles, folkloristics, riddles

The article analyses colour names in the three most widely spread subgenres of Estonian riddles - classical or ordinary riddles, conondrums, and droodles - focusing on the specific features of each subgenre and their specific differences. The main questions concern the more frequent colour names by subgenres, their more general usage relations, and the use of colours in image creation. Classical riddles belong to a more archaic layer and are, by their nature, poetic descriptions of an object or a phenomenon, in which the image expresses mainly the appearance of the answer object, the facets perceived by senses. Colour names occur frequently in the image creation of riddles, serving as primary indicators in describing an object or a phenomenon and providing a hint at the answer.

Classical riddles manifest the importance of colours in the semantic-lexical imagery of riddles (image stereotypes and form patterns), which can roughly be divided into two: 1. In texts with defined subjects, in which the image coincides with the syntactic subject of the descriptive sentence, the subject is often a zoological term, which is complemented by a colour (e.g. clichés such as grey/black/white ox; black pig and red piglets); yet, colour is also essential in human images (e.g. black man, red boy). 2. Texts with undefined subjects, in which the object to be guessed is presented indirectly by means of its activity, qualities, relations, places, time, etc., and colour names are applied in form stereotypes based on some kind of paradoxical differences or contradictions.

Conondrums and droodles as more recent subgenres are oriented on humour; they both express cultural stereotypes and symbols by means of colours. As compared to the colour statistics of classical riddles, in conondrums the leading position is occupied by 
the subject-related term 'blond', which marks a fair-haired and fair-skinned person, and is caused by the multitude of jokes about dim-witted blondes that became popular in the second half of the 1990s. Colours play an important role in the absurd questions beginning in 'What is...?', as well as internationally known absurd series of elephantquestions, in which the opposition of two colour shades (light-dark, white-black) is widely spread as a humour-creating method. The colour image of the black-and-white droodles often contains the inducing of visual imagination and the occurrence of colour in both the question and answer.

Text examples originate from internet databases Estonian Riddles (Krikmann \& Krikmann 2012), Estonian Conondrums (Voolaid 2004), and Estonian Droodles (Voolaid 2002), based mainly on the manuscript material of the Estonian Folklore Archives as well as different publications and internet material. 